University of Nebraska - Lincoln

DigitalCommons@University of Nebraska - Lincoln

Publications, Agencies and Staff of the U.S.

Department of Commerce

U.S. Department of Commerce

2008

\title{
Linking Colonies to Fisheries: Spatio-Temporal Overlap Between \\ Common Murres (Uria aalge) from Tatoosh Island and Coastal Gillnet Fisheries in the Pacific Northwest, USA
}

\author{
Nathalie J. Hamela \\ University of Washington \\ Julia K. Parrisha \\ University of Washington \\ Jeff Laake \\ National Marine Mammal Laboratory, Alaska Fisheries Science Center, National Marine Fisheries Service
}

Follow this and additional works at: https://digitalcommons.unl.edu/usdeptcommercepub

Part of the Environmental Sciences Commons

Hamela, Nathalie J.; Parrisha, Julia K.; and Laake, Jeff, "Linking Colonies to Fisheries: Spatio-Temporal Overlap Between Common Murres (Uria aalge) from Tatoosh Island and Coastal Gillnet Fisheries in the Pacific Northwest, USA" (2008). Publications, Agencies and Staff of the U.S. Department of Commerce. 200.

https://digitalcommons.unl.edu/usdeptcommercepub/200

This Article is brought to you for free and open access by the U.S. Department of Commerce at DigitalCommons@University of Nebraska - Lincoln. It has been accepted for inclusion in Publications, Agencies and Staff of the U.S. Department of Commerce by an authorized administrator of DigitalCommons@University of Nebraska - Lincoln. 


\title{
Linking colonies to fisheries: Spatio-temporal overlap between common murres (Uria aalge) from Tatoosh Island and coastal gillnet fisheries in the Pacific Northwest, USA
}

\author{
Nathalie J. Hamel ${ }^{a, *}$, Julia K. Parrish ${ }^{a}$, Jeff Laake \\ aniversity of Washington, Box 355020, Seattle, WA 98195, USA \\ ${ }^{\mathrm{b}}$ National Marine Mammal Laboratory, Alaska Fisheries Science Center, National Marine Fisheries Service, 7600 Sand Point Way NE, \\ Seattle, WA 98115, USA
}

\section{A R T I C L E I N F O}

\section{Article history:}

Received 6 October 2007

Received in revised form

29 August 2008

Accepted 15 September 2008

Available online 26 October 2008

Keywords:

Bycatch

Driftnet fisheries

Guillemots

Mark-recapture

Multistrata models

Telemetry

\begin{abstract}
A B S T R A C T
The population-level impact of seabird bycatch is difficult to assess because colony-of-origin is often unknown. As an alternative and complementary approach to ship-derived observations, we assessed the relative potential for bycatch of a known seabird population by quantifying spatio-temporal overlap with local fisheries. Common murres (Uria aalge) have been reported as the most abundant seabird inadvertently caught in Washington and British Columbia coastal gillnet fisheries. In 1999-2001, we tracked 48 common murres from Tatoosh Island, the closest colony to the fisheries, during post-breeding. Using capture-mark-recapture models, we estimated weekly murre movement probabilities to/from three strata (offshore of, centered around, and inshore of Tatoosh Island). Based on movement probabilities and population size, we projected strata- and week-specific murre abundance. We created an index of overlap by calculating the product of murre abundance $\times$ gillnet fishing effort as a function of strata and time. The majority of murres (80\%) moved inshore, where fishing effort was consistently the highest, suggesting that up to 4000 Tatoosh murres were vulnerable to bycatch. Index scores in the inshore stratum were 5-25 times higher relative to the offshore and Tatoosh strata, respectively. Overlap was sensitive to phenology, as index scores increased by $50 \%$ when dispersal was shifted four weeks earlier, while a two weeks delay decreased scores by $20 \%$. Until the long-term impact of cumulative mortality in gillnet fisheries is determined, we believe a precautionary approach is warranted in the inshore stratum where the potential for bycatch was highest. We advocate the use of visible netting in inshore fisheries, a proven solution that reduces murre bycatch while maintaining fishing efficiency.
\end{abstract}

(c) 2008 Elsevier Ltd. All rights reserved.

\section{Introduction}

Bycatch is regarded as a serious conservation issue as it wastes commercial and non-commercial species, alters food webs, and depletes populations (Crowder and Murawski, 1998; Morgan and Chuenpagdee, 2003). Although a wide vari- ety of organisms have been reported as bycatch, the incidental capture of long-lived, low-fecundity species is of particular concern, as even slightly elevated adult mortality rates can cause population decline (Russell, 1999). Seabirds, in particular, are vulnerable to incidental take during fishing (Brothers et al., 1999b; Kelleher, 2005). Despite worldwide reporting of

* Corresponding author: Tel.: +1 206221 6904; fax: +1 2062216939.

E-mail addresses: nhamel@u.washington.edu (N.J. Hamel), jparrish@u.washington.edu (J.K. Parrish), jeff.laake@noaa.gov (J. Laake). 0006-3207/\$ - see front matter (c) 2008 Elsevier Ltd. All rights reserved. doi:10.1016/j.biocon.2008.09.015 
seabird bycatch (Lewison et al., 2005), population-level impacts have been difficult to characterize because it is rarely possible to assign colony-of-origin to birds hauled on board (Lewison et al., 2004; Abbott et al., 2006; Bull, 2007), making it difficult to link fisheries activities to the conservation status of populations (Cuthbert et al., 2005).

Typically, bycatch data are reported by fisheries observers or in fishery logbooks (Lewison et al., 2004). However, many fisheries worldwide have no observer program or suffer under-reporting of bycatch (Crowder and Murawski, 1998; Lewison et al., 2004). As an alternative and complementary approach to ship-borne reporting, assessment of the interactions between particular populations of conservation concern and specific fisheries can allow for: the relative evaluation of fisheries threat as a function of space and time (Cuthbert et al., 2005; Goldsworthy and Page, 2007); the potential for identification of life-history stages prone to risk (Weimerskirch et al., 2006); and, ultimately, the potential to inform sciencebased measures for effective conservation and management solutions (BirdLife International, 2004; Karpouzi et al., 2007). This approach relies on predicting the spatio-temporal distribution of organisms from known populations or dispersal sites, often with the use of electronic transmitters (Read and Westgate, 1997; James et al., 2005; Phillips et al., 2006).

In the Pacific Northwest of North America, seabird bycatch has been reported in Washington and British Columbia coastal gillnet fisheries since at least the early 1980s (Carter and Sealy, 1984; Kaiser, 1993; Thompson et al., 1998; Melvin et al., 1999; Smith and Morgan, 2005). Commercial gillnet fisheries have operated in these regions for decades, principally targeting salmonids (Shepard and Argue, 2005). Despite significant regional reductions in landings and of fishing fleets (S. Boessow, Washington Department of Fish and Wildlife (WDFW), unpublished data; Nelson and Turris, 2004; Department of Fisheries and Oceans Canada, 2007; Sea Around Us, 2007), gillnetting has persisted and was worth $\$ 25$ million annually from 2000 to 2006 in Washington and British Columbia combined (L. Hoines, WDFW, unpublished data; Department of Fisheries and Oceans Canada, 2007). The majority of the reported bird bycatch has been common murres (Uria aalge) (Pierce et al., 1994; Melvin et al., 1999; Smith and Morgan, 2005) and, in some of the fisheries, annual mortality estimates were in the thousands (Pierce and Alexandersdottir, unpublished data in Thompson et al., 1998; Smith and Morgan, 2005). The provenance of these murres is unknown although colonies in the vicinity of the fishing grounds are an obvious potential source. However, murres from throughout the Pacific Northwest, and possibly farther afield (e.g., California), migrate to the outer coast of Washington, Strait of Juan de Fuca (SJDF) and Puget Sound after the breeding season (Manuwal and Carter, 2001). Therefore, understanding the spatial and temporal extent of postbreeding migration patterns is critical to the process of evaluating population-level impact of these fisheries on murres.

Whereas millions of common murres breed in Alaska and hundreds of thousands nest in California and Oregon, Washington and British Columbia support only tens of thousands of this species (Carter et al., 2001; Ainley et al., 2002; Hipfner, 2005). In 2002, the last year of comprehensive surveys in Washington, approximately 10,400 murres were counted at colonies in the state (J. Parrish, unpublished data; Wilson, 2003). The population size in Washington is one-third of pre-1980 estimates (Carter et al., 2001), and the species is considered a state species of concern (Washington Department of Fish and Wildlife, 2007). The majority of Washington murres nest at a single location, Tatoosh Island, the closest colony to the northern Washington and southern British Columbia gillnet fisheries (Fig. 1). After a period of rapid increase following human abandonment of the island, colony attendance declined (approximately 3\% per year) throughout the 1990s, and has since been increasing (J. Parrish, unpublished data, Paine et al., 1990; Parrish et al., 2001). Colony declines on the West Coast of the USA have been attributed to various causes including bycatch in gillnet fisheries (Takekawa et al., 1990; Carter et al., 2001), oil spills (Burger, 1993), climatic events (Wilson, 1991), and predation by bald eagles (Haliaeetus leucocephalus) (Parrish et al., 2001), but the relative importance of each is unknown (Carter et al., 2001).

Using radio-telemetry, capture-mark-recapture models, and fisheries effort data, we quantified the spatio-temporal overlap between the Tatoosh Island murre population and the local gillnet fisheries in Washington and British Columbia to determine whether this population was vulnerable to fisheries bycatch. We designed an index of overlap to determine when and where the potential for bycatch was greatest. Our results have direct natural resource management and conservation application, as they identify the intensity and location of potential seabird-fisheries interactions, allowing effective focused management action to reduce seabird bycatch.

\section{Methods}

\subsection{Capture site and tagging}

Tatoosh Island is located at $48^{\circ} 23^{\prime} \mathrm{N}, 123^{\circ} 44^{\prime} \mathrm{W}$, approximately $10 \mathrm{~km}$ south of the international border with Canada, at the confluence of the SJDF and the Pacific Ocean (Fig. 1). Common murres were captured at dusk from blinds on the edge of two large (approximately 1000 birds) nesting areas and tagged with VHF radio-transmitters between 23 July and 8 August each year (5 in 1999; 18 in 2000; 25 in 2001). A blood sample (approximately 2 cc) was taken from the tarsus for genetic sex-determination. Transmitters used in 1999 were manufactured by Advanced Telemetry Systems (Isanti, Minnesota; model 2032-prong) and Holohil Systems in 20002001 (Carp, Ontario; model R1-2B). Devices were attached with a sub-cutaneous anchor (Newman et al., 1999). Each transmitter ( $6-8 \mathrm{~g}$ or $<1 \%$ of body weight), equipped with a $20 \mathrm{~cm}$ whip antenna projecting at a $30^{\circ}$ angle, emitted a unique frequency in the $150-151 \mathrm{MHz}$ range. Batteries lasted up to three months. We tagged 38 breeders parenting a chick, and 10 non-breeders. Our sample included 30 females and 18 males.

\subsection{Aerial tracking}

To re-locate tagged murres after transmitter deployment, we conducted aerial tracking surveys from a Cessna 172 aircraft. 


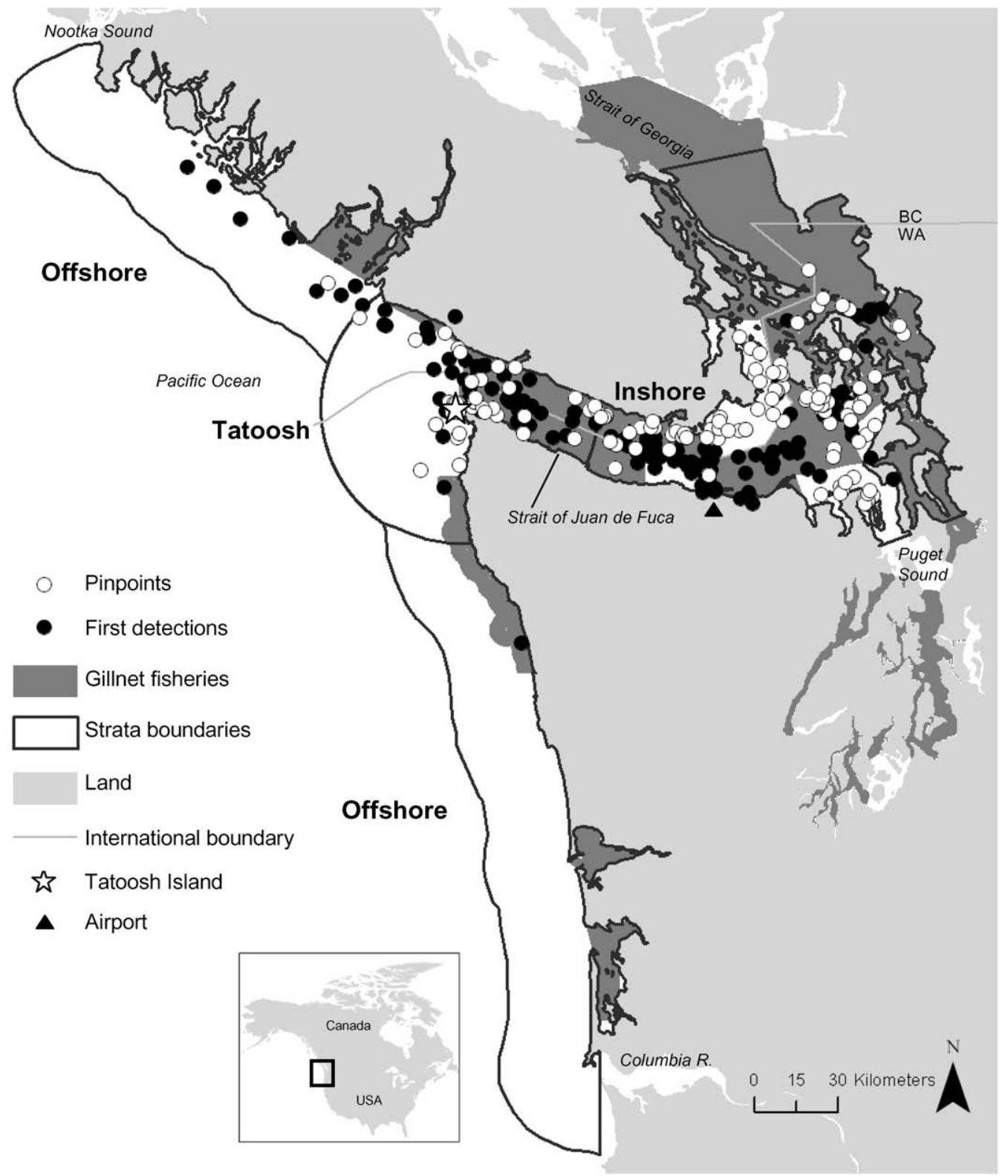

Fig. 1 - Study site, spanning Washington (WA) and British Columbia (BC). Strata names are to the left of respective boundaries. Pinpoints $(n=168)$ and first detections $(n=154)$ are shown for all months (August to October) and years (19992001). Gillnet fisheries with one or more boat.days annual average (1999-2001) are shaded with dark grey. Area of study is boxed in inset.

Two 4-element Yagi antennas mounted on each wing strut were linked via a signal switchbox to a receiver (Advanced Telemetry Systems model R-2000) programmed to scan continuously, stopping on each frequency for $4 \mathrm{~s}$. In the majority of the cases when a frequency was first encountered, we recorded the position (latitude, longitude and altitude) of the aircraft using GPS (Magellan 300, accuracy $12 \mathrm{~m}$ ). Following this first detection, we manually halted the scan-cycle, and boxed in the signal according to the "right-angle turn" technique (Seddon and Maloney, 2004). Once the signal strength remained maximal, the aircraft position was again recorded, hereafter termed a pinpoint. After pinpointing, the frequency was deleted from the scanning cycle and the aircraft resumed course. Mean pinpoint error $(0.9 \mathrm{~km} \pm 0.4 \mathrm{SD}$; range 0.4
$1.6 \mathrm{~km}, n=8$ tests) was estimated as the distance between pinpoints and transmitters situated in known locations during blind test trials.

In 2000 and 2001, we could not pinpoint all detected signals due to the greater number of transmitters and limited tracking time. To maximize our sample size, we used two types of locations: pinpoints $(n=168)$ and first detections that were not followed by a pinpoint in the same flight $(n=154)$ (Fig. 1). We applied a circular error buffer of $2 \mathrm{~km}$ radius around pinpoints (the maximum test trial error of $1.6 \mathrm{~km}$, rounded to the nearest kilometer). We applied an error buffer of $35 \mathrm{~km}$ radius around the first detections because $95 \%$ of pinpoints were detected within $35 \mathrm{~km}$ of their associated first detection $(n=113)$. We removed the portions of the buffers 
that overlaid land because we assumed birds remained on or over water. This yielded a maximum buffer area of $25 \mathrm{~km}^{2}$ and $7700 \mathrm{~km}^{2}$ for pinpoints and first detections, respectively.

\subsection{Search area and strata}

Our search area spanned the outer coasts of Washington and British Columbia, from the Columbia River north to Nootka Sound, and the inland marine waters of Puget Sound and the Strait of Georgia (Fig. 1). Typical cruising altitude and air speed were approximately $610 \mathrm{~m}$ and $130 \mathrm{~km} / \mathrm{h}$, respectively. To ensure complete coverage of the study area, aerial transects were planned based on a conservative detection distance of $10 \mathrm{~km}$ (mean detection distance was $20 \mathrm{~km} \pm 11 \mathrm{SD}, n=113$ ) such that our search swath was $20 \mathrm{~km}$ wide. Radio interference precluded signal detection in south Puget Sound, therefore this region was excluded from our analyses (Fig. 1). Flights began around $10 \mathrm{Au}$ gust, i.e., a few days before we expected the first tagged bird to depart the island at the end of the breeding season, and ended by 22 October each year. For the first two weeks, we concentrated our search effort in the SJDF and around Tatoosh Island as murres were still on or just leaving the colony. After 2 weeks, once most chicks of tagged birds had fledged, we tracked across the entire search area. Because the search area was large $\left(27,000 \mathrm{~km}^{2}\right)$, we created search sections (offshore north, offshore south, SJDF, Strait of Georgia) and rotated flights systematically with the aim of surveying all sections weekly.

\subsection{Capture-mark-recapture analysis}

Tracking over a large area, failure or loss of transmitters, temporary or permanent emigration and mortality can result in not all transmitters detected during any given survey. To cope with incomplete detections of tagged murres, we used multistate capture-mark-recapture (CMR) modeling, which is useful to assess spatial and temporal movement probabilities among the states (strata) while allowing for uncertainty in transmitter detection (Arnason, 1973; Hestbeck and Nichols, 1991; Lebreton and Pradel, 2002).

We divided the search area into three strata (Fig. 1). The "Tatoosh" stratum $\left(4781 \mathrm{~km}^{2}\right)$ included all waters within a $50 \mathrm{~km}$ radius (the foraging range of murres; Ainley et al., 2002), of Tatoosh Island. "Inshore" $\left(8273 \mathrm{~km}^{2}\right)$ was defined as the area east of the Tatoosh stratum encompassing the SJDF, north Puget Sound and south Strait of Georgia. "Offshore" $\left(13,291 \mathrm{~km}^{2}\right)$ included a $30 \mathrm{~km}$-wide band paralleling the British Columbia and Washington coastlines (Fig. 1). The width of the offshore band was determined by applying the mean detection distance $(20 \mathrm{~km})$ to the offshore transect which was located no farther than $10 \mathrm{~km}$ out from the coast for safety reasons. Because flights could only cover a portion of the entire search area each day, we aggregated our data into 11 sequential weekly recapture occasions starting 8 August and ending 17 October.

\subsection{Encounter histories}

For each of the 48 tagged murres, we constructed an encounter history detailing the 11 recapture occasions as a function of space (strata) and time (weeks). Each occasion was assigned a single stratum by overlaying the associated week's pinpoint and first detection locations and their respective buffers on the strata map using the Identity function in the XTools Pro 3.0.0 extension in ESRI ArcMap 9.1. If a bird was detected multiple times within a week, the recapture was assigned to the stratum with the majority of the locations. Pinpoint and first detection buffers fell within one stratum in $97 \%$ and $60 \%$ of the cases, respectively. When buffers straddled multiple strata, we chose the stratum containing the majority of the buffer. Finally, we assigned zeroes to all weeks in which a bird was not detected.

\subsection{Model parameters}

Multistrata models are representations of the observed encounter histories using detection (recapture) probabilities $(p)$, survival probabilities $(\phi)$ and movement probabilities $(\psi)$. For our study, the parameter of interest was movement probability $\left(\psi^{\mathrm{rs}}\right)$ or the conditional probability a live tagged murre in stratum $r$ moved to stratum $s$ from one week to the next. Each of these probabilities potentially varied over time, strata and individuals; however, with only 48 birds, we necessarily limited our candidate models to portray a few primary sources of variation.

\subsection{Detection probability}

A live murre with a functional radio-transmitter could go undetected because the aircraft was not within the detection range, atmospheric noise interfered with detection, and/or the bird was diving repeatedly or temporarily left the search area. We expected atmospheric noise blanketing radio-signals to be most problematic in the vicinity of urban areas in the inshore stratum. We also expected spatial and temporal differences due to varying amounts of survey effort each week. Therefore, differences in detection probability between strata were our primary concern because if ignored, they could influence our assessment of movement probabilities.

Although we expected spatio-temporal variation in detection probability, the number of parameters for the general models was too large (99 and 35 for the full interaction or additive models, respectively). Therefore, we modeled the variation in detection probability using search effort (Table 1). We calculated the amount of search effort for each of the 99 possible strata-week combinations in $\mathrm{km}^{2}$ by applying a $20 \mathrm{~km}$ swath (the mean detection distance) on either side of the plane's track. Inclement weather, plane availability, intensified search effort in the Tatoosh and inshore strata, and differences in strata size resulted in heterogeneous search effort among strata-week combinations. More effort was deployed in the inshore stratum (total is $177,597 \mathrm{~km}^{2}$ or $52 \%$ of total search effort), than in the Tatoosh $\left(86,501 \mathrm{~km}^{2}, 25 \%\right)$ or offshore $\left(79,137 \mathrm{~km}^{2}, 23 \%\right)$ strata. In all models, we fixed to zero the detection probabilities for the 31 strata-week cells with no search effort and defined a scaled effort covariate as the search effort divided by stratum area (or effort density).

\subsection{Apparent survival}

We refer to apparent rather than actual survival because we could not distinguish between the effects of mortality, trans- 
Table 1 - Model parameters and their notation. All are main effects only unless otherwise specified as an interaction (")

\begin{tabular}{|c|c|c|}
\hline Model notation & Number of parameters & Definition \\
\hline Modelling $\phi$ & & Apparent survival probability \\
\hline$\phi$ & 1 & Constant survival probability \\
\hline Modelling $p$ & & Detection probability \\
\hline$p$ & 1 & Constant detection probability \\
\hline$p_{\mathrm{s}}$ & 3 & Detection probability is strata-dependent \\
\hline$p_{\text {effort }}$ & 2 & Search effort as a covariate \\
\hline$p_{\mathrm{s}+\text { effort }}$ & 4 & ...dependent on strata with search effort covariate \\
\hline$p_{\mathrm{s}+\text { effort+s+effort }}$ & 6 & ...dependent on strata with search effort covariate and their interaction \\
\hline Modelling $\psi$ & & Movement probability \\
\hline$\psi$ & 1 & Constant movement probability \\
\hline$\psi_{\mathrm{rs}}$ & 4 & Movement probability is strata-dependent. Stratum of origin is $r$ and destination stratum is $\mathrm{s}$ \\
\hline$\psi_{\mathrm{w} 1 \mathrm{w} 3}$ & 2 & ...time-dependent where weeks are binned into two categories (weeks 1 and 2; weeks 3-12) \\
\hline$\psi_{\mathrm{rs}+\mathrm{w} 1 \mathrm{w} 3}$ & 5 & ...strata- and time-dependent \\
\hline
\end{tabular}

mitter failure or loss and permanent emigration from the search area. Given the high annual survival of murres elsewhere in the California Current System (i.e., approximately 90\%) (Lee and Sydeman, 2006), the short 11-week study duration, and relatively uniform colony attendance and climatic conditions (e.g., no El Niño) during the study, we discounted actual mortality as influential on apparent survival. We had no a priori reason to believe Tatoosh murres would disperse only within our search area or evenly across exterior boundaries, so permanent emigration may have influenced our estimates of apparent survival. However, we expected that transmitter failure or loss were the primary sources of signal loss, possibly highest towards the end of each study year. We initially explored models where apparent survival was occasion- and/or strata-dependent, but we did not include them in the final set of candidate models (Table 1) because these models failed to converge. Furthermore, it was apparent in this initial exploration that survival could be reasonably held constant for each occasion.

\subsection{Movement}

We never observed birds transitioning directly from offshore to inshore or vice-versa and thus modeled movement of murres from Tatoosh to inshore or offshore and back as well as of murres remaining within a stratum. To capture the timing of the pulse of birds moving away from the island once the breeding season was over, we examined models with a single shift in movement rates, i.e., categorizing weeks into two time periods. We initially explored a series of models with constant survival and detection probability but with different change points for the shift in movement rates. The model with the change point at week 3 (w1w3: weeks 1 and 2 were combined and weeks 3 through 11 were combined; Table 1) was consistently the most parsimonious. We also initially examined models with a year, sex, breeding status (breeder or non-breeder), and post-breeding status (i.e., whether the bird is a male traveling with a chick or not) effect, but our small sample size precluded this level of detail. However, as our sampling strategy did not target particular types of adult birds, and our sample included all of the above life-history stages, we assumed our sample was broadly representative of the population-level pattern.

CMR models require instantaneous sampling to avoid movement among strata within sampling periods (Hestbeck and Nichols, 1991; Nichols and Kendall, 1995). In our study, a sampling period took place over sequential days aggregated into weekly capture occasions during which time murres had the opportunity to move between strata. This meant that transitions between strata may have been missed. However, $83 \%$ of the birds transitioned at most once to another stratum over the entire study period, suggesting relatively low frequency of movement across strata boundaries thereby minimizing the impacts of this violation of assumption.

\subsection{Model fitting and selection}

Combinations of the various sub-models in Table 1 resulted in 20 candidate models. The full model was

$P_{\text {s+effort }+ \text { s*effort }} \phi \psi_{\text {rs+w1w3 }}$

Models were fitted to the data using program MARK (White and Burnham, 1999), as described by Cooch and White (2007), and input files were built using the RMark interface (R Development Core Team, 2005; Laake and Rexstad, 2006) which uses formula notation to create the necessary parameter structure and design matrix. The multinomial logit link was used for $\psi$ and the logit link was used for $p$ and $\phi$. The most parsimonious model was selected based on Akaike's information criterion for small samples (AICc) (Burnham and Anderson, 2002).

\subsection{Goodness-of-fit model}

To assess the goodness-of-fit of the full model, we compared the observed and expected weekly encounters of birds in each stratum using a Pearson $\chi^{2}$ test. Expected counts were generated for each week, strata and year using the model and estimated parameters. Expected values for each stratum-week combination were summed across the three years to obtain counts greater than two to improve the $\chi^{2}$ approximation. We also calculated a variance inflation factor 
$\hat{c} \cong \frac{\chi^{2}}{d f}$

to adjust the AICc value in the case of overdispersion (when $\hat{c}>1$; Burnham and Anderson, 2002). We also used U-CARE (Choquet et al., 2005) as a more general goodness-of-fit for multi-state models.

\subsection{Murre spatial and temporal distribution}

We projected the abundance of Tatoosh Island murres in each of the three strata during the course of the 11-week study by simulating movement while taking into account the stochastic nature of movement and parameter uncertainty. For each replicate of the simulation, the starting population size was 5910 murres, or the average attendance at Tatoosh Island in 1999-2001 (3539 \pm 13 adults, including non-breeders and breeders; J. Parrish, unpublished data and Parrish et al., 2001), corrected by a factor of 1.67 to account for absent breeders (Carter et al., 2001). All birds started in the Tatoosh stratum and were distributed across each stratum each week using a multinomial sampling distribution. Birds were distributed from the inshore and offshore strata using a binomial sampling distribution because the birds could remain there or move to Tatoosh. The movement probabilities from the best model were used as parameters of the sampling distributions. However, to address uncertainty in the movement parameter estimates, we randomly drew a set of movement probabilities from a multivariate normal (MVN) error distribution at each simulation replicate. The MVN distribution used the beta values of the movement probability estimates (on the multinomial logit scale) as expectations and their estimated variance-covariance matrix. Once a new set of multinomial logit parameters were drawn from the MVN distribution, they were converted back to "real" movement probabilities (values between 0 and 1) and used as the probabilities for the multinomial/binomial distributions for the 11-week simulation replicate. Our simulations assumed that no birds were added or lost due to mortality or emigration/immigration. We empirically determined that the mean number of birds for each strata and week was stable if we used 500 projections.

\subsection{Fisheries statistics}

We included all commercial and test drift gillnet fisheries within Washington and southern British Columbia. In these fisheries, a monofilament net is fixed to the vessel, with both drifting together. Net length is either $375 \mathrm{~m}$ (in British Columbia) or $550 \mathrm{~m}$ (in Washington and British Columbia) (Department of Fisheries and Oceans Canada, 1993; Department of Fisheries and Oceans Canada, 1999; Washington Department of Fish and Wildlife, 2000).

Information for British Columbia fisheries was obtained from the Department of Fisheries and Oceans Canada (DFO), the Nitinat Gillnet Bycatch Study Program at DFO and the Pacific Salmon Commission. The WDFW provided treaty (Native American) and non-treaty fisheries information for Washington. Owing to a lack of detailed fishing effort data and taking into account differences between management agencies, we developed a proxy measure of fishing effort based on daily estimates of boats fishing in each stratum as boat.days per week per stratum. In British Columbia, effort was generated for each relevant stratum by summing the average daily boat counts performed during the DFO aerial fishery surveys over the number of days the fishery was open in a week. In Washington, direct boat counts were not available. Instead, we used records of fish sales reported to the WDFW. One transaction is reported per boat and buyer, and boats typically sell their day's catch to a single buyer. Thus, effort for the State was estimated by summing the number of transactions in each week in each stratum. For all weeks and strata, fishing effort was estimated annually over the 1999-2001 period for the purposes of the overlap analysis. We also compiled longer-term gillnet fisheries effort (British Columbia, 1990-2001; Washington, 19702005).

\subsection{Potential for bycatch: overlap analysis}

To evaluate the potential for bycatch, we created an index of spatio-temporal overlap similar to the "birds $\times$ hooks" index developed in Cuthbert et al. (2005). Our index integrated abundance of Tatoosh Island murres and Washington and British Columbia gillnet fishing effort and scored the overlap in each stratum-week combination:

$I_{\text {iy }}^{\mathrm{s}}=\frac{N_{i}^{\mathrm{s}} \times E_{i y}^{\mathrm{s}}}{Z_{\mathrm{s}}} \times 100 \mathrm{~km}^{2}$

where, an index score, $I_{i y}^{\mathrm{s}}$, is equal to the product of the estimated murre abundance in week $i$ in each stratum $s\left(N_{i}^{\mathbf{s}}\right)$ and the fishing effort, in boat.days, in each stratum in each week in each year y $\left(E_{i y}^{\mathrm{s}}\right)$ divided by stratum size $\left(Z_{\mathrm{s}}\right)$ and standardized to $100 \mathrm{~km}^{2}$ units. The index takes on a value from 0 (no potential for bycatch) to infinity, increasing when the number of murres and/or fishing effort increases within a stratum. Thus, whether there are 100 murres and 10 units of fishing effort, or 10 murres and 100 units of fishing effort in a given stratum, the index score is equal. We used sums and averages of the index scores across weeks, strata and/or years as metrics to facilitate comparisons.

\subsection{Scenarios}

To understand the impact of changes in murre post-breeding dispersal timing, we bracketed our index results with two scenarios. In the first, we shifted our projected murre dispersal to four weeks earlier (as in years with early colony departures); in the second, we shifted the distribution two weeks later (delayed departure). To equalize the time window for comparisons, we extended our original study period such that scenarios encompassed the majority of the fishing effort, and they started and ended the same weeks: 6 June-26 November. We assumed that all birds were in the Tatoosh stratum before dispersal began, and that numbers in all strata were fixed after the 11th week.

\section{Results}

\subsection{Data summary}

All tagged murres were detected at least once, although there was a significant exponential decrease in the number 


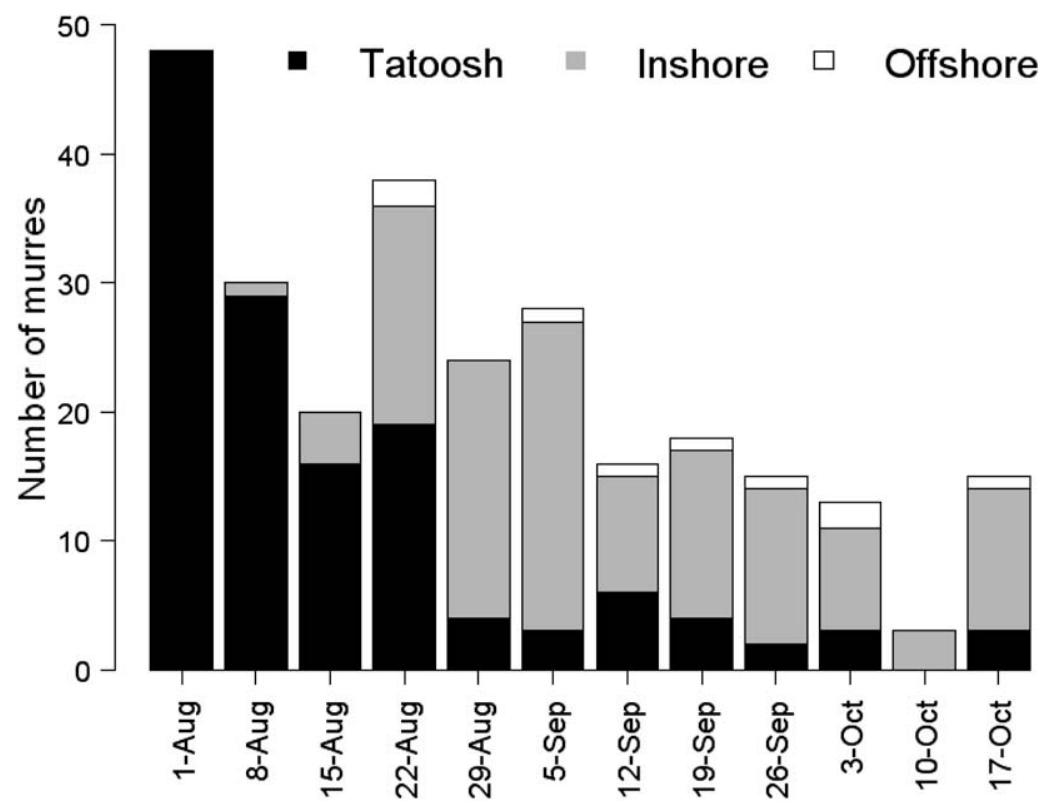

Fig. 2 - Number of tagged murres detected each week in each stratum, 1999-2001.
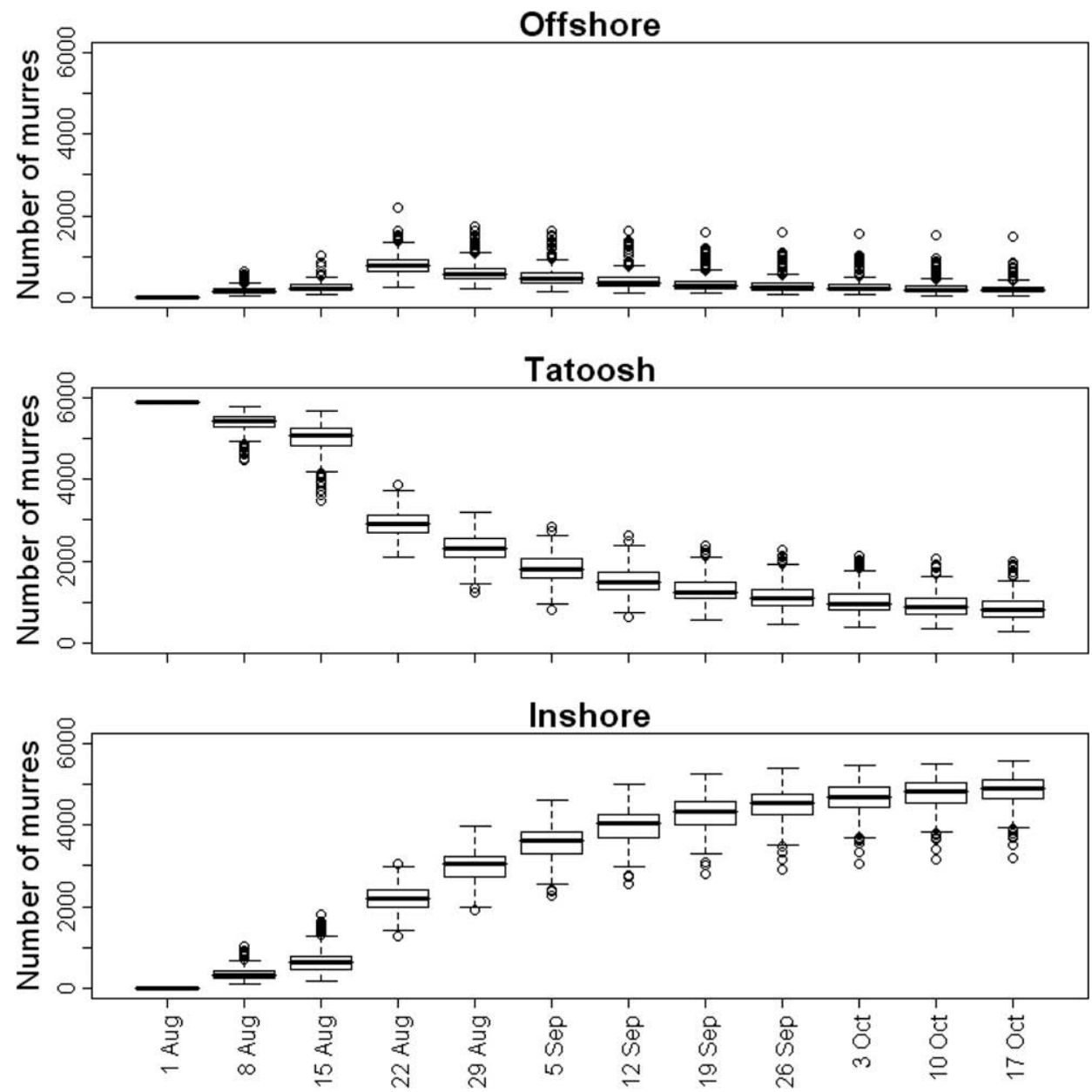

Fig. 3 - Simulation results $(n=500)$ of the projected number of murres in each stratum and week, based on the best model's movement probabilities and an initial population size of 5910 Tatoosh Island murres. In each boxplot, the thick line represents the median. The bottom and top of box shows the 25 and 75 percentiles, respectively. The whiskers are equal to $1.5 \times$ the interquartile range and circles represent outliers. 


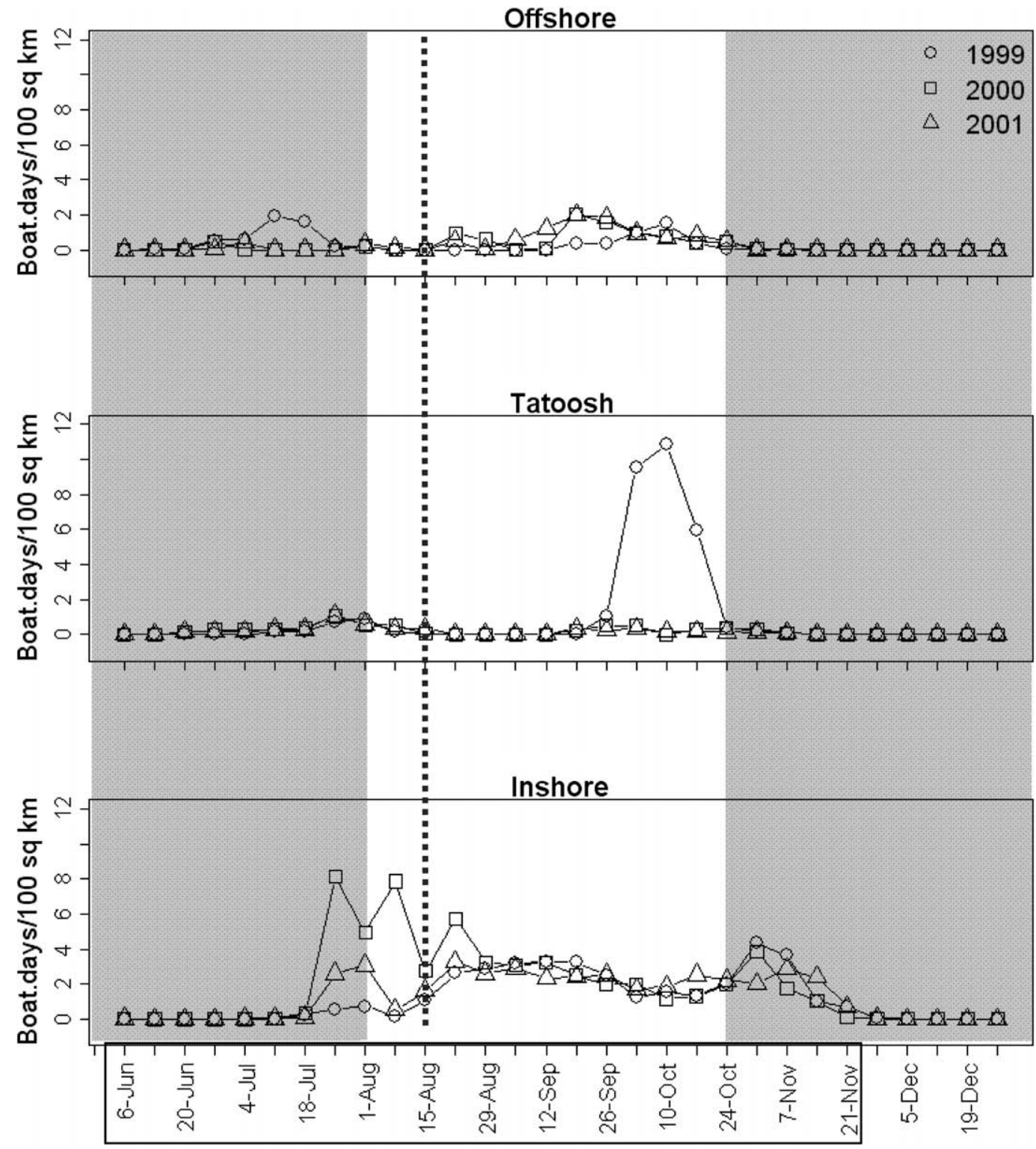

Fig. 4 - Fishing effort, as proxied by the weekly boat.days per $100 \mathrm{~km}^{2}$ of strata, during three years in each stratum. The study period (1 August-22 October) is unshaded. The dotted line indicates the initiation of post-breeding dispersal of tagged murres based on model results. Boxed dates bracket the time window of shifted dispersal scenarios.

of detected birds over time. Only one-third remained in the sample by the last week $\left(r^{2}=0.98\right.$, slope $=-0.117, P<0.0001$ for log-transformed bird data), further justifying our use of constant apparent survival in the CMR models. On average, each bird was detected $7 \pm 5 \mathrm{SD}$ times (range 1-18). After collapsing the detections into a weekly location, the mean number of recaptures per bird was $6 \pm 3$ SD (range 1-10), with a total of 268 non-zero encounters out of 528 total possible bird-week encounters. All birds were first detected in the Tatoosh stratum (Fig. 2). By the second week (8-14 August), we began to detect murres inshore. After 29 August, the majority of the detections came from inshore (Fig. 2). Throughout the entire period, few birds were detected offshore (Figs. 1 and 2).

\subsection{Model fitting and selection}

Predictions from the full model did not demonstrate any significant lack of fit from the observed data using our simplified test $\left(\chi^{2}=23.2, \mathrm{df}=21, P=0.34\right)$ or the U-CARE test $\left(\chi^{2}=15.3\right.$, $\mathrm{df}=20, P=0.76)$. The variance inflation factor from the full model ( $\hat{c}=1.10$ or 0.76 ) did not indicate any significant concern for over-dispersion, so we assumed $\hat{c}=1$ (Cooch and White, 2007) and used an unadjusted AICc.

Of the 20 models in the candidate set, the full model was best supported, carrying $99 \%$ of the weight (Table 2). The top three models included a spatial and temporal component for movement probability, as well as an effect of search effort and stratum on detection. The large drop in weight between 
Table 2 - Selection scores of multistrata models for top four multistrata models that we examined, the number of parameters (np), the Akaike Information Criterion corrected for small sample sizes (AICc), the difference in AIC between the model and the best model $(\triangle \mathrm{AICc})$ and the relative support for each model ( $A I C c_{\text {weight }}$ )

\begin{tabular}{|c|c|c|c|c|}
\hline Model & $\mathrm{np}$ & AICc & $\triangle \mathrm{AICc}$ & AIC $_{\text {weight }}$ \\
\hline$\phi p_{\mathrm{s}+\text { effort+sxeffort }} \psi_{\mathrm{rs}+\mathrm{w} 1 \mathrm{w} 3}$ & 12 & 1431.9 & 0.0 & 0.99 \\
\hline$\phi p_{\mathrm{s}+\text { effort }} \psi_{\mathrm{rs}+\mathrm{w} 1 \mathrm{w} 3}$ & 10 & 1444.7 & 9.7 & 0.008 \\
\hline$\phi p_{\text {effort }} \psi_{\mathrm{rs}+\mathrm{w} 1 \mathrm{w} 3}$ & 8 & 1447.8 & 15.8 & 0.0004 \\
\hline$\phi p_{\text {s+effort+sxeffort }} \psi_{\text {w1w3 }}$ & 9 & 1450.5 & 18.5 & 0.0000 \\
\hline
\end{tabular}

the top two models was driven only by the removal of the interaction term to detection probability in the weaker model (Table 2).

\subsection{Detection and apparent survival rates}

In the best model, detection probability was a function of search effort, stratum and their interaction. Estimates were generally constant in the Tatoosh and offshore strata and more variable in the inshore stratum. During those occasions with non-zero search effort in the Tatoosh stratum (20 out of 33 occasions), detection was complete. Detection probability was lower offshore, with the non-zero detections $(n=15)$ equal to 0.68 , consistent with the lower search effort deployed in this region. Inshore, detectability varied between 0.18 and $1.00(n=29)$, but was generally high $(64 \%$ of the occasions over 0.75). Apparent weekly survival rate was $0.91 \pm 0.90 \mathrm{SE}$.

\subsection{Movement rate}

The movement probabilities generated by the best model indicated that during the first two weeks of our study (1-14 August), most birds remained in the Tatoosh stratum (Table 3). By the third week of August, the majority of murres had initiated their post-breeding dispersal, a pattern that underlies the time categories selected in the modeling process (weeks 1-2; weeks 3-12; Table 3). Movement rates increased primarily out of the Tatoosh and offshore strata, although the majority of murres did not move between strata (Table 3). Most murres heading away from Tatoosh went inshore and remained there (Table 3).

\subsection{Murre spatial and temporal distribution}

The projected number of murres in the Tatoosh stratum decreased only slightly over the first three weeks (Fig. 3). By the 4th week (22 August), the median number of murres in the Tatoosh stratum had dropped by $50 \%$, eventually reaching a plateau of approximately 1000 birds. Concurrently, the median number of murres increased threefold in the inshore stratum before reaching an asymptote of approximately 4500 birds, or $76 \%$ of the Tatoosh population. Median offshore abundance never exceeded $13 \%$ of the Tatoosh population.

\subsection{Fisheries effort}

During all three years, the fishing season ranged from June to November encompassing our study period. Effort was concentrated inshore (Fig. 4), where fishing occurred during all weeks. By contrast, there was no fishing in the Tatoosh and offshore strata, in about half of the study weeks. In those strata, effort tended to be lower (1-2 boat.days $/ 100 \mathrm{~km}^{2}$ ), except in October 1999 when effort in the Tatoosh stratum peaked at 10 boat.days $/ 100 \mathrm{~km}^{2}$. Fishing typically began in late June or July, while murres were still at the colony. The end of the fishing season coincided with the end of our study, except inshore, where fishing continued through November.

\subsection{Overlap}

Our results indicated that murres from Tatoosh Island overlapped both in space and time with Washington and/or British Columbia commercial gillnet fisheries in all strata and years. However, the period of overlap was wider and in-

Table 3 - Weekly estimates of movement probabilities from best model with standard errors, for the two time categories

\begin{tabular}{llll} 
& Offshore & Tatoosh & Inshore \\
\hline 1 August-14 August & & & 0.01 \\
Tatoosh & $0.07 \pm 0.05$ & $0.91 \pm 0.03$ & $1.0 \pm 0.00$ \\
Inshore & 0 & $0.06 \pm 0.02$ & 0 \\
Offshore & $0.93 \pm 0.05$ & $0.02 \pm 0.01$ & $0.04 \pm 0.02$ \\
15 August-22 October & & & $0.96 \pm 0.02$ \\
Tatoosh & $0.37 \pm 0.15$ & $0.57 \pm 0.06$ & 0 \\
Inshore & 0 & $0.11 \pm 0.05$ & \\
Offshore & $0.63 \pm 0.15$ & &
\end{tabular}

Strata of origin are in the first row and destination strata are in the first column. 
dex scores were 5-25 times greater in the inshore stratum than in the other two strata ( $\bar{\chi} \pm$ SE inshore: $86,743 \pm 2353$, Tatoosh 16,046 \pm 7951 and offshore $3476 \pm 943$; Fig. 5). This pattern was a result of the larger fraction of birds moving into the eastern SJDF (Fig. 3), combined with sustained fishing effort in all but one week (Fig. 4). During the last three weeks, the inshore index scores were lower as numbers of birds reached a plateau and fishing effort diminished. Within the Tatoosh stratum, there was overlap from 1 to 22 August (when most birds were still within the stratum), and from $19 \mathrm{Sep}$ tember to the end of the study, when fall fishing began (Figs. 3-5). Index scores in the offshore stratum were uniformly low, because of few birds (Fig. 3) and limited fishing effort (Fig. 4). Yearly index results (i.e., weekly index scores summed across the three strata), were $117,158,103,474$ and 98,162 in 1999, 2000 and 2001, respectively.

\subsection{Scenarios}

Assuming no change in dispersal and effort location, earlier dispersal of murres from the island resulted in an increase in the index scores, by as much as $51 \%$ (year 2000), relative to the "no shift" scenario (Table 4). On the other hand, a shift to two weeks later resulted in a decrease in index scores, of up to $21 \%$. Therefore, our results suggest that the potential for bycatch could be substantially higher, or lower, depending on dispersal timing.

\section{Discussion}

Common murres from Tatoosh Island dispersed after the breeding season into areas where seabirds have been known to interact with commercial gillnet fisheries and where substantial bycatch has been reported (Troutman et al., 1991; Pierce et al., 1994; Thompson et al., 1998; Melvin et al., 1999; Smith and Morgan, 2005). Most murres from Tatoosh Island (approximately 80\%) went inshore (Fig. 3), where fishing effort was typically highest relative to the other two strata (Fig. 4). However, the potential for interaction with gillnet fisheries existed even while the birds were still on the colony, as fishing began in the Tatoosh stratum approximately eight weeks before fledging. By late-September, birds and fisheries overlapped throughout the study region. Collectively, these results suggest that the Tatoosh Island murre population was vulnerable to gillnet fishery bycatch, and that the potential for bycatch was greatest inshore (Fig. 5).

Although our calculated overlap values in the inshore stratum were already relatively high, our post-hoc scenarios indi-
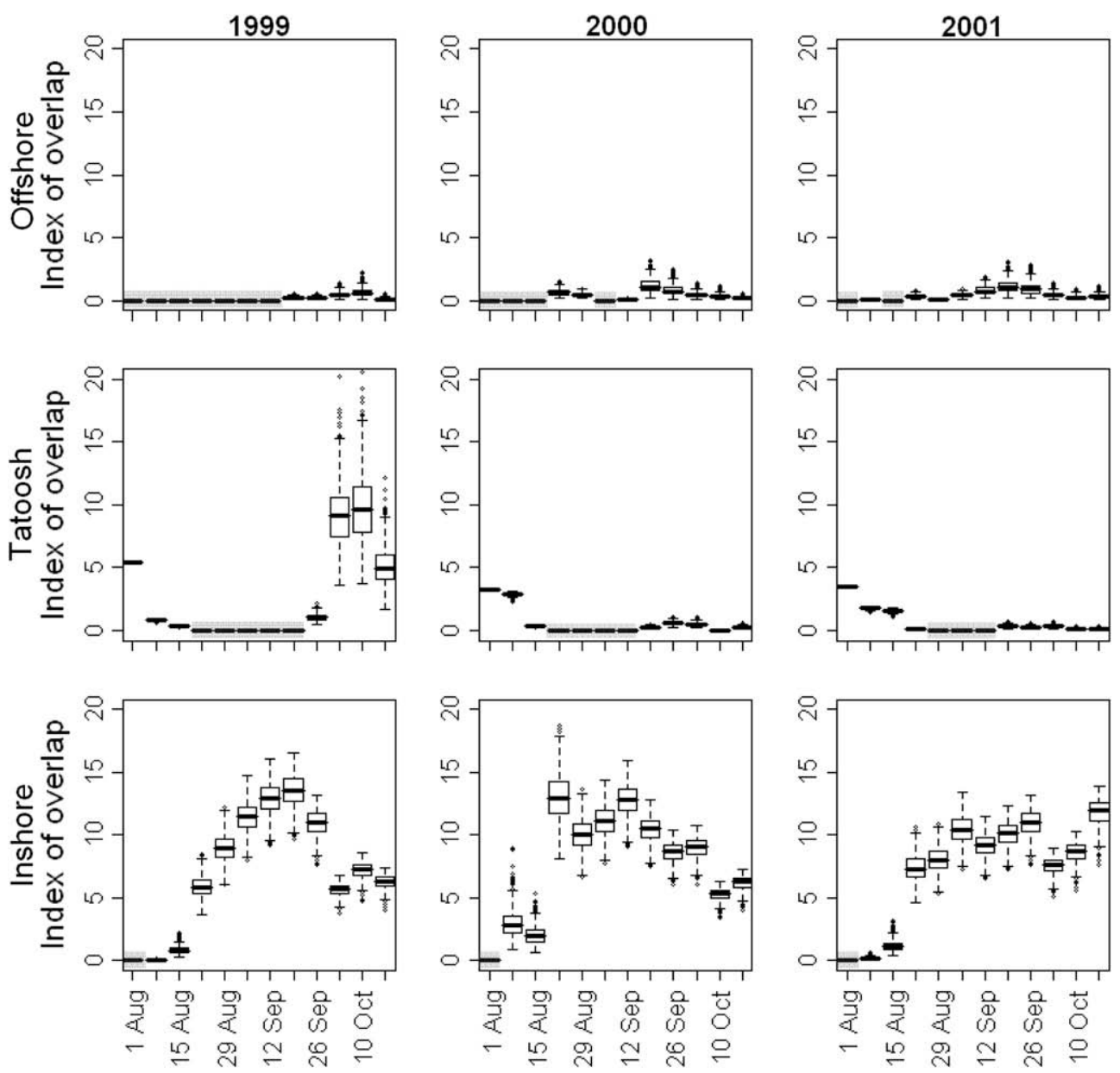

Fig. 5 - Boxplots of spatio-temporal overlap index (bird.boat.days $/ 100 \mathrm{~km}^{2} \times 1000$ ) for 1999-2001. Gray shading indicates zeroes. All other formatting as in Figure 4. 
Table 4 - Annual index values as a result of shifting dispersal four weeks early or two weeks late relative to no shifting

\begin{tabular}{cccc} 
Year & Early & Late & No shift \\
\hline 1999 & $191,200(+9 \%)$ & $155,951(-11 \%)$ & 174,772 \\
2000 & $239,512(+51 \%)$ & $125,181(-21 \%)$ & 158,405 \\
2001 & $183,707(+19 \%)$ & $132,981(-14 \%)$ & 154,926 \\
\hline
\end{tabular}

The values in this table are the sum of index values across weeks and strata with the \% difference relative to the no shift scenario in parentheses.

cated that minor temporal shifts in dispersal could have substantially increased, or decreased, the degree of overlap (Table 4). Both seabird and fisheries abundance and distribution are subject to variability in space and time as a function of natural and management forcing (Boekelheide et al., 1990; Suryan et al., 2004; Lehodey et al., 2006). For instance, in years of low food availability (e.g., El Niño) laying may be late by up to one month, effectively delaying dispersal (Farallon Islands, CA: Boekelheide et al., 1990) which would decrease the overlap between Tatoosh Island murres and gillnet fisheries. By contrast, in high predator pressure (e.g., eagle harassment) years, murres may prematurely abandon the colony (J. Parrish, unpublished data), advancing dispersal and putting Tatoosh Island murres at greater risk. Of course, changes in the amount of fisheries effort could swamp minor shifts in breeding/dispersal phenology. In fact, annual gillnet fishing effort in Washington and British Columbia was up to 10 times as high in the 1970s and 1980s as compared to recent years (Fig. 6), suggesting that the potential for bycatch may have been substantially higher during those decades.

Spatio-temporal overlap between seabirds and fisheries is a necessary precondition for bycatch; however, it is not necessarily a good predictor of bycatch at the local (i.e., boat) scale. Factors including individual vessel effects (Dietrich, 2003), time of day (Nel et al., 2002b) or weather conditions (Brothers et al., 1999a) may modulate interaction rates between seabirds and fishery gear. However, at relatively larger scales (e.g., years or regions) and specifically in our study system, annual seabird abundance in the SJDF has been shown to fluctuate in parallel with bycatch rates (Melvin et al., 1999; Melvin et al., 2001). Given that bird counts from our projections were summarized for a similar spatial scale (e.g., the inshore stratum encompassed most of the SJDF plus a portion of the southern Strait of Georgia), our overlap index is a reasonable proxy for the relative potential for bycatch in each stratum and week. However, our index cannot be translated directly into actual bycatch because the fate of individuals never seen again is unknown. In the year subsequent to tagging, approximately $50 \%$ of our tagged birds were observed at the colony (Hamel et al., 2004). Even if we assume mortality as the fate of the remaining birds, we have no way of ascribing mortality singly or predominantly to gillnet fisheries in our study area.

Efforts to study the dispersal of seabirds to ascertain their vulnerability to fisheries have been mostly limited to larger seabirds able to carry satellite transmitters (Boersma et al., 2002; Nel et al., 2002a; Hyrenbach and Dotson, 2003; BirdLife International, 2004; Cuthbert et al., 2005; Small, 2005; Phillips et al., 2006; Small and Taylor, 2006; Suryan et al., 2007). However, smaller seabirds can constitute a significant fraction of bycatch (DeGange et al., 1993; Artyukhin and Burkanov, 2000; Melvin et al., 2001; Baker and Wise, 2005). Murres, in particular, have been reported as bycatch in many coastal fisheries throughout their range (Piatt and Nettleship, 1987; Takekawa et al., 1990; Forney et al., 2001; Österblom et al., 2002; Davoren, 2007). Satellite telemetry has had limited success with common murres (Hatch et al., 2000), whereas radiotransmitters have been used with no significant lethal, sublethal or demographic consequences (Hamel et al., 2004). Therefore, until satellite transmitters are further miniaturized, radio-telemetry remains one of the most appropriate techniques for the study of small seabird dispersal into coastal environments where human activities pose a threat.

Evaluating overlap is an increasingly popular approach to assess the vulnerability of seabirds to fisheries. For instance, overlap methods were have been applied to identify the regional fisheries management organizations that posed a risk for birds in the high seas (Small, 2005). Other uses could include the design of fisheries observer programs where bycatch sampling effort can be stratified in space and time as a function of overlap. Applied more broadly, this approach could be used to determine potential for interaction with other anthropogenic threats (e.g., oil spills) or, more positively, for species protection in the design of marine protected areas (Karpouzi et al., 2007).

Determining seabird-fisheries overlap allows targeted management actions in areas, at times, and for species, for which the risk is highest, such that restrictive measures are not unnecessarily applied. For instance, Cuthbert et al. (2005) used a spatio-temporal index to show that although while breeding Tristan albatross (Diomedea dabbenena) overlapped with many pelagic longline fisheries, index scores of specific fleets were substantially higher, suggesting that targeted management action could significantly reduce seabird bycatch. Simultaneously, Goldsworthy and Page (2007) used a foraging model to simulate the distribution of Australian sea lions (Neophoca cinerea) and New Zealand fur seals (Arctocephalus forsteri) relative to both pot and demersal gillnet fisheries. Calculated interaction probabilities suggested that the risk of extinction was highest for sea lions interacting with demersal gillnets, but lower-to-inconsequential for all other species-fishery combinations. In our study, the inshore stratum clearly received most of the murres and sustained the highest fishery effort, suggesting management actions should be primarily focused in this region. However, even within a single stratum, murres did not use space uniformly (Fig. 1). Additional data (e.g., daily pinpoints) to refine the spatial and temporal resolution of bird locations could improve the accuracy of our overlap index and further refine which jurisdictions and times are most risky for murres. 

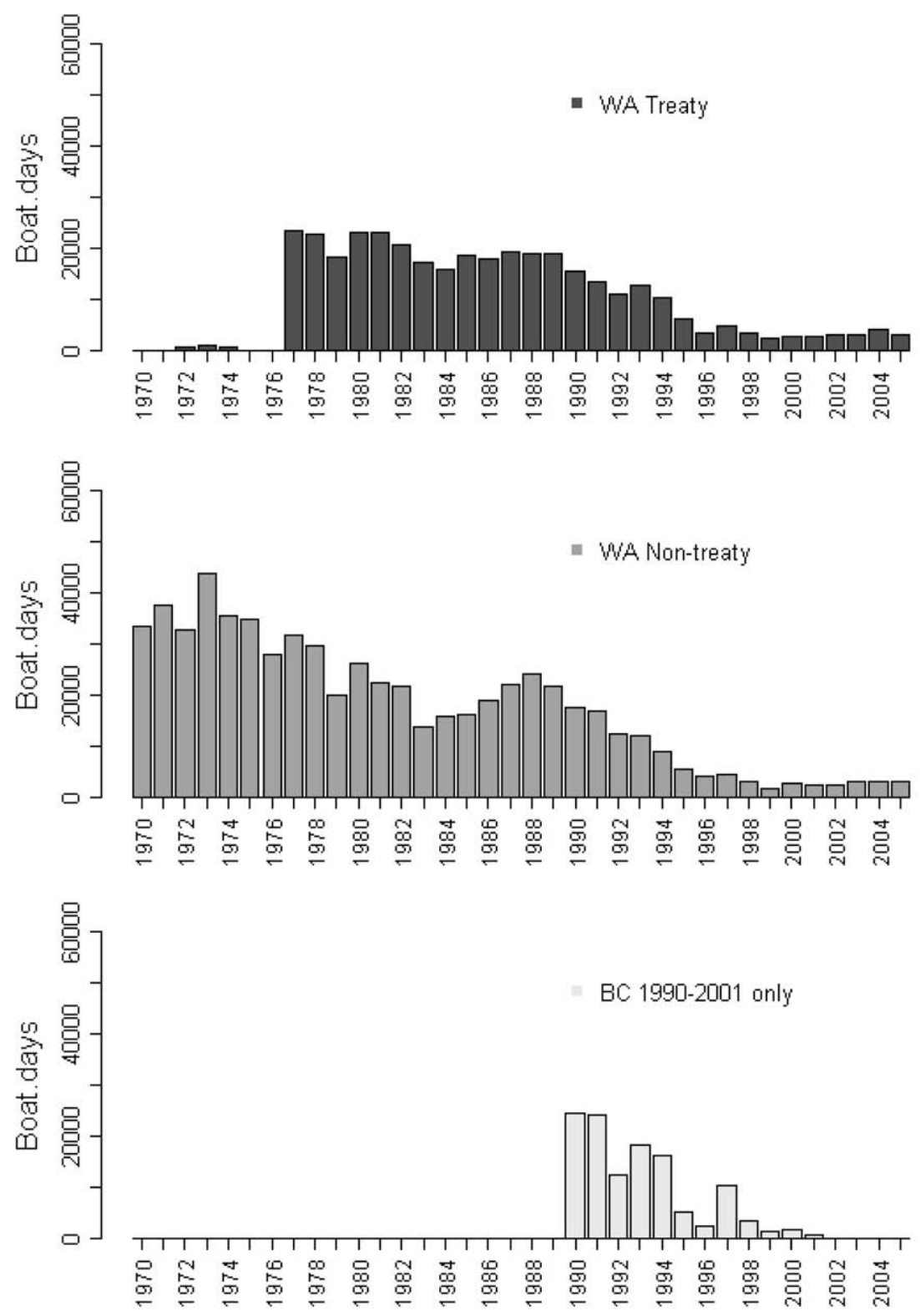

Fig. 6 - Annual sum of gillnet fisheries effort for Washington (WA) treaty and non-treaty fisheries, and British Columbia (BC). We had complete data for BC between 1990 and 2001 only. Landings from treaty fisheries were consistently recorded starting in 1977.

Given substantial seabird mortality and the possibility of killing endangered marbled murrelets, the WDFW adopted regulations to reduce seabird bycatch in 1999 in the nontreaty gillnet fishery for sockeye and pink salmon in the eastern SJDF (Melvin et al., 1999; Harrison, 2001). The action mandated daytime fishing with modified nets shown to reduce seabird, and specifically murre, bycatch by up to $55 \%$ without reducing fishing efficiency (Melvin et al., 1999). Unfortunately, the non-treaty sockeye and pink salmon fishing fleet accounts for only $10 \%$ of the total gillnet catch in weight in British Columbia and Washington (L. Hoines, WDFW, unpublished data; Department of Fisheries and Oceans Canada, 2007; Harrison, 2001). Therefore, murres continue to be vulnerable to gillnet fisheries in the inshore stratum.
Due to socio-cultural, political, and financial importance, it is likely that some level of gillnet fishing, and thus bycatch of seabirds, will continue in Pacific Northwest inside waters. Uncertainty can impede conservation action because the burden of proof lies on the side of conservation, and often action occurs too late, i.e., when a population is already declining or on the brink of extinction (Taylor et al., 2000). On the other hand, we must determine whether or not fisheries have an impact on marine populations to avoid penalizing the industry unnecessarily, as well as to make sound decisions about how to distribute limited resources for conservation actions (Wilcox and Donlan, 2007). In this study, we cannot attribute spatio-temporal overlap to a specific fishery, nation or tribe, as we consolidated multiple fisheries in each stratum. Neither 
can we conclusively demonstrate that bycatch had a population-level impact on Tatoosh Island murres. However, our study did demonstrate that potential for bycatch of murres from Tatoosh Island was relatively high in the inshore stratum and that up to 4000 birds may be vulnerable to bycatch, annually. Therefore, we advocate a precautionary approach (Garcia, 1994) and recommend expanding the use of visible netting to all inshore gillnet fisheries to reduce seabird, and specifically murre, bycatch across all fishery sectors regardless of colony-of-origin, and to reduce the degree of long-term impact of cumulative fishery bycatch on the Tatoosh Island murre population, in particular.

\section{Acknowledgements}

This study was funded by Washington Sea Grant (award no. NA76RG0019, project R/F-131) and Pacific Northwest Coastal Ecosystem Regional Study (PNCERS; grant no. NA96OP0238). The School of Aquatic and Fishery Sciences at the University of Washington provided scholarships to N. Hamel. We thank L. Hoines and S. Boessow at WDFW, and L. Hop Wo and L. Keary and J. Mitchell at DFO for supplying fisheries data. We also thank J. Huckabee, D. Deghetto and staff at the Wildlife Department at PAWS, and S. Newman and R. Whitney for lending their tagging expertise. We acknowledge $\mathrm{K}$. Warheit from the WDFW for sexing analyses, and Rite Bros, Inc. for their piloting experience during aerial tracking. We are also are grateful to S. Zador, B. Chasco, J. Smith, P. Wade, E. Melvin, P. Hodum, D. Hyrenbach, K. Morgan, J. Dolliver, C. French, E. Hagen, B. Harms, J. Scuzs and I. Ortiz for lending their expertise in the field, in the lab, or for reviewing drafts of this manuscript. Finally, we thank the anonymous reviewers who offered many helpful comments. This research was approved by University of Washington Institutional Animal Care and Use Committee, the US Fish and Wildlife Service and the WDFW.

\section{R E F E R E N C E S}

Abbott, C.L., Double, M.C., Gales, R., Baker, G.B., Lashko, A., Roberston, C.J.R., Ryan, P.G., 2006. Molecular provenance analysis for shy and white-capped albatrosses killed by fisheries interactions in Australia, New Zealand, and South Africa. Conservation Genetics 7, 531-542.

Ainley, D.G., Nettleship, D.N., Carter, H.R., Storey, A.E., 2002. Common murre (Uria aalge). In: Poole, A., Gill, F. (Eds.), The Birds of North America, vol. 661. The Birds of North America, Inc., Philadelphia, PA.

Arnason, A.N., 1973. The estimation of population size, migration rates and survival in a stratified population. Researches on Population Ecology 15, 1-18.

Artyukhin, Y.B., Burkanov, V.N., 2000. Incidental mortality of seabirds in the drift net salmon fishery by Japanese vessels in the Russian Exclusive Economic Zone, 1993-97. In: Kondratyev, A.Y., Litvinenko, N.M., Kaiser, G.W. (Eds.), Seabirds of the Russian Far East. Canadian Wildlife Service, Ottawa, pp. 105115.

Baker, G.B., Wise, B.S., 2005. The impact of pelagic longline fishing on the flesh-footed shearwater Puffinus carneipes in Eastern Australia. Biological Conservation 126, 306-316.
BirdLife International, 2004. Tracking ocean wanderers: the global distribution of albatrosses and petrels. In: Results from the Global Procellariiform Tracking Workshop, 1-5 September, 2003, Gordon's Bay, South Africa. BirdLife International, Cambridge, UK.

Boekelheide, R.J., Ainley, D.G., Morrell, S.H., Huber, H.R., Lewis, T.J., 1990. Common murre. In: Ainley, D.G., Boekelheide, R.J. (Eds.), Seabirds of the Farallon Islands. Stanford Univ. Press, Stanford, CA, pp. 245-275.

Boersma, P.D., Stokes, D.L., Strange, I.J., 2002. Applying ecology to conservation: tracking breeding penguins at New Island South reserve, Falkland Islands. Aquatic Conservation: Marine and Freshwater Ecosystems 12, 63-74.

Brothers, N., Gales, R., Reid, T., 1999a. The influence of environmental variables and mitigation measures on seabird catch rates in the Japanese tuna longline fishery within the Australian Fishing Zone, 1991-1995. Biological Conservation 88, 85-101.

Brothers, N.P., Cooper, J., Løkkeborg, S., 1999b. The incidental catch of seabirds by longline fisheries: worldwide review and technical guidelines for mitigation. FAO Fish Circular No. 937.

Bull, L.S., 2007. Reducing seabird bycatch in longline, trawl and gillnet fisheries. Fish and Fisheries 8, 31-56.

Burger, A.E., 1993. Interpreting the mortality of seabirds following the Nestucca oil spill of 1988-1989. Canadian Wildlife Service Technical Report Series 178. Canadian Wildlife Service, Pacific and Yukon Region, Delta, BC.

Burnham, K.P., Anderson, D.R., 2002. Model Selection and Multimodel Inference: A Practical Information-theoretic Approach, second ed. Springer, New York.

Carter, H.R., Sealy, S.G., 1984. Marbled murrelet mortality due to gill-net fishing in Barkley Sound, British Columbia. In: Nettleship, D.N., Sanger, G.A., Springer, P.F. (Eds.), Marine Birds: Their Feeding Ecology and Commercial Fisheries Relationships. Canadian Wildlife Service, Special Publication, Ottawa, pp. 212-220.

Carter, H.R., Wilson, U.W., Lowe, R.W., Rodway, M.S., Manuwal, D.A., Takekawa, J.E., Yee, J.L., 2001. Population trends of the common murre (Uria aalge californica). In: Manuwal, D.A., Carter, H.R., Zimmermann, T.S., Orthmeyer, D.L. (Eds.), Biology and Conservation of the Common Murre in California, Oregon, Washington, and British Columbia, Natural History and Population Trends, vol. 1. US Geological Survey, Washington, DC (Information and Technology Report USGS/BRD/ITR-20000012).

Choquet, R., Reboulet, A.-M., Lebreton, J.-D., Gimenez, O., Pradel, R., 2005. U-CARE 2.2 User's Manual. CEFE, Montpellier, France.

Cooch, E., White, G., 2007. Program MARK: A Gentle Introduction. sixth ed. <http://www.phidot.org/software/mark/docs/book/> (retrieved July 2007).

Crowder, L., Murawski, S.A., 1998. Fisheries bycatch: implications for management. Fisheries 23 (6), 8-17.

Cuthbert, R., Hilton, G., Ryan, P., Tuck, G.N., 2005. At-sea distribution of breeding Tristan albatrosses Diomedea dabbenena and potential interactions with pelagic longline fishing in the South Atlantic Ocean. Biological Conservation 121, 345-355.

Davoren, G.K., 2007. Effects of gill-net fishing on marine birds in a biological hotspot in the Northwest Atlantic. Conservation Biology 21, 1032-1045.

DeGange, A.R., Day, R.H., Takekawa, J.E., Mendenhall, V.M., 1993. Losses of seabirds in gill nets in the North Pacific. In: Vermeer, K., Briggs, K.T., Morgan, K.H., Siegel-Causey, D. (Eds.), The Status, Ecology, and Conservation of Marine Birds of the North Pacific. Canadian Wildlife Service, Ottawa, pp. 204-211.

Department of Fisheries and Oceans Canada, 1993. Pacific Fishery Regulations. <http://laws.justice.gc.ca/en/F-14/SOR-93-54/ index.html $>$ (retrieved 20.06.07). 
Department of Fisheries and Oceans Canada, 1999. Pacific region 1999 salmon net management plan - Areas B, D and E South Coast and Fraser River. <http://www-ops2.pac.dfo-mpo.gc.ca/ xnet/content/MPLANS/archive/1999/SBDE99PL.PDF> (retrieved 20.06.07).

Department of Fisheries and Oceans Canada, 2007. Summary Commercial Statistics. <http://www.pac.dfo-mpo.gc.ca/sci/sa/ Commercial/AnnSumm_e.htm> (retrieved 20.06.07).

Dietrich, K.S., 2003. Factors affecting seabird bycatch in Alaska longline fisheries. M.S. Thesis. University of Washington, Seattle, Washington, USA.

Forney, K.A., Benson, S.R., Cameron, G., 2001. Central California effort and bycatch of sensitive species, 1990-1998. In: Melvin, E., Parrish, J.K. (Eds.), Seabird Bycatch: Trends, Roadblocks, and Solutions. University of Alaska Sea Grant, AK-SG-01-01, Fairbanks, AK.

Garcia, S.M., 1994. The precautionary principle: its implications in capture fisheries management. Ocean and Coastal Management 22, 99-125.

Goldsworthy, S.D., Page, B., 2007. A risk-assessment approach to evaluating the significance of seal bycatch in two Australian fisheries. Biological Conservation 139, 269-285.

Hamel, N.J., Parrish, J.K., Conquest, L.L., 2004. Effects of tagging on behavior, provisioning, and reproduction in the common murre (Uria aalge), a diving seabird. The Auk 121, 1161-1171.

Harrison, C.S., 2001. Epilogue revisited: constraints to seabird conservation in Northwest salmon drift gillnet fisheries. In: Melvin, E.F., Parrish, J.K. (Eds.), Seabird Bycatch: Trends, Roadblocks and Solutions. University of Alaska Sea Grant, AKSG-01-01, Fairbanks, AK, pp. 185-189.

Hatch, S.A., Meyers, P.M., Mulcahy, D.M., Douglas, D.C., 2000. Performance of implantable satellite transmitters in diving seabirds. Waterbirds 23, 84-94.

Hestbeck, J.B., Nichols, J.D., 1991. Estimates of movement and site fidelity using mark-resight data of wintering Canada Geese. Ecology 72, 523-533.

Hipfner, J.M., 2005. Population status of the common murre Uria aalge in British Columbia, Canada. Marine Ornithology 33, 6769.

Hyrenbach, K.D., Dotson, R.C., 2003. Assessing the susceptibility of female black-footed albatross (Phoebastria nigripes) to longline fisheries during their post-breeding dispersal: an integrated approach. Biological Conservation 112, 391-404.

James, M.C., Ottensmeyer, C.A., Myers, R.A., 2005. Identification of high-use habitat and threats to leatherback sea turtles in northern waters: new directions for conservation. Ecology Letters 8, 195-201.

Kaiser, G.W., 1993. Seabird wreck in Boundary Bay. Pacific Seabird Group Bulletin Fall 1993, 18-20.

Karpouzi, V., Watson, R., Pauly, D., 2007. Modelling and mapping resource overlap between seabirds and fisheries on a global scale: a preliminary assessment. Marine Ecology Progress Series 343, 87-99.

Kelleher, K., 2005. Discards in the World's Marine Fisheries: An Update. Food and Agriculture Organization of the United Nations, Rome, Italy.

Laake, J., Rexstad, E., 2006. RMark - an alternative approach to building linear models in MARK. In: Cooch, E., White, G. (Eds.), Program MARK: a Gentle Introduction. <http:// www.phidot.org/software/mark/docs/book/pdf/app_3.pdf > (retrieved July 2007).

Lebreton, J.D., Pradel, R., 2002. Multi-state re-capture models: modelling incomplete individual histories. Journal of Applied Statistics 29, 353-369.

Lee, D.E., Sydeman, W.J., 2006. Population vital rates for common murres (Uria aalge) of Southeast Farallon Island, California. A report to the California Department of Fish and Game - office of oil spill prevention and response, PRBO Conservation
Science, Marine Ecology Division. <http://www.dfg.ca.gov/ ospr/organizational/scientific/ssep/final_reports/Lee\%20 and\%20Sydeman\%202006\%20COMU\%20demographics.pdf> (retrieved May 2007).

Lehodey, P., Alheit, J., Barange, M., Baumgartner, T., Beaugrand, G., Drinkwater, K., Fromentin, J.M., Hare, S.R., Ottersen, G., Perry, R.I., Roy, C., Van der Lingen, C.D., Werner, F., 2006. Climate variability, fish, and fisheries. Journal of Climate 19, 5009-5030.

Lewison, R.L., Crowder, L.B., Read, A.J., Freeman, S.A., 2004. Understanding impacts of fisheries bycatch on marine megafauna. Trends in Ecology and Evolution 19, 598-604.

Lewison, R.L., Nel, D.C., Taylor, F., Croxall, J.P., Rivera, K.S., 2005. Thinking big- taking a large-scale approach to seabird bycatch. Marine Ornithology 33, 1-5.

Manuwal, D.A., Carter, H.R., 2001. Natural history of the common murre (Uria aalge californica). In: Carter, H.R., Wilson, U.W., Lowe, R.W., Rodway, M.S., Manuwal, D.A., Takekawa, J.E., Yee, J.L. (Eds.), Biology and Conservation of the Common Murre in California, Oregon, Washington, and British Columbia, Natural History and Population Trends, vol. 1. US Geological Survey, Washington, DC. Information and Technology Report USGS/ BRD/ITR-2000-0012.

Melvin, E.F., Parrish, J.K., Conquest, L.L., 1999. Novel tools to reduce seabird bycatch in coastal gillnet fisheries. Conservation Biology 13, 1386-1397.

Melvin, E.F., Parrish, J.K., Dietrich, K.S., Hamel, O.S., 2001. Solutions to seabird bycatch in Alaska's demersal longline fisheries. Washington Sea Grant Program. Project A/FP-7, Seattle, WA.

Morgan, L., Chuenpagdee, R., 2003. Shifting Gears: Addressing the Collateral Impacts of Fishing Methods in USA Waters. Island Press Publication Services, Washington, DC.

Nel, D.C., Ryan, P.G., Nel, J.L., Klages, N.T.W., Wilson, R.P., Robertson, G., Tuck, G.N., 2002a. Foraging interactions between wandering albatrosses Diomedea exulans breeding on Marion Island and longline fisheries in the southern Indian Ocean. Ibis 144, E141-E154.

Nel, D.C., Ryan, P.G., Watkins, B.P., 2002b. Seabird mortality in the Patagonian toothfish longline fishery around the Prince Edward Islands, 1996-2000. Antarctic Science 14, 151-161.

Nelson, S., Turris, B., 2004. The Evolution of Commercial Salmon Fisheries in British Columbia. Prepared for the Pacific Fisheries Resource Conservation Council, Vancouver, BC.

Newman, S.H., Takekawa, J.Y., Whitmorth, D.L., Burkett, E.E., 1999. Subcutaneous anchor attachment increases retention of radio transmitters on xantus' and marbled murrelets. Journal of Field Ornithology 70, 520-534.

Nichols, J.D., Kendall, W.L., 1995. The use of multi-state capturerecapture models to address questions in evolutionary ecology. Journal of Applied Statistics 22, 835-846.

Österblom, H., Fransson, T., Olsson, O., 2002. Bycatches of common guillemot (Uria aalge) in the Baltic Sea gillnet fishery. Biological Conservation 105, 309-319.

Paine, R.T., Wootton, J.T., Boersma, P.D., 1990. Direct and indirect effects of peregrine falcon predation on seabird abundance. The Auk 107, 1-9.

Parrish, J.K., Marvier, M., Paine, R.T., 2001. Direct and indirect effects: interactions between bald eagles and common murres. Ecological Applications 11, 1858-1869.

Phillips, R.A., Silk, J.R.D., Croxall, J.P., Afanasyev, V., 2006. Yearround distribution of white-chinned petrels from South Georgia: relationships with oceanography and fisheries. Biological Conservation 129, 334-336.

Piatt, J.F., Nettleship, D.N., 1987. Incidental catch of marine birds and mammals in fishing nets off Newfoundland, Canada. Marine Pollution Bulletin 18, 344-349.

Pierce, J.D., Ritchie, W.P., Kreuziger, R., 1994. Preliminary Findings of Seabird Interactions with the Non-treaty Salmon Gillnet 
Fishery: Puget Sound and Hood Canal Washington.

Washington Department of Fish and Wildlife, Olympia.

R Development Core Team, 2005. R: A Language and Environment for Statistical Computing (version 2.2.1). R Foundation for Statistical Computing, Vienna, Austria. <http://www.Rproject.org>.

Read, A.J., Westgate, A.J., 1997. Monitoring the movements of harbour porpoises (Phocoena phocoena) with satellite telemetry. Marine Biology 130, 315-322.

Russell, R.W., 1999. Comparative demography and life-history tactics of seabirds: implications for conservation and marine monitoring. In: Musick, J.A. (Ed.), Life in the Slow Lane: Ecology and Conservation of Long-Lived Marine Animals, vol. 23. American Fisheries Symposium, pp. 51-76.

Sea Around Us, 2007. A Global Database on Marine Fisheries and Ecosystems. Fisheries Centre, University British Columbia, Vancouver (British Columbia, Canada). $<$ www.seaaroundus.org> (retrieved 16.08.07).

Seddon, P.J., Maloney, R.F., 2004. Tracking wildlife radio-tag signals by light fixed-wing aircraft. Department of Conservation Technical Series, 30.

Shepard, M.P., Argue, A.W., 2005. The 1985 Pacific Salmon Treaty: Sharing Conservation Burdens and Benefits. UBC Press, Vancouver, BC, Canada.

Small, C., Taylor, F., 2006. Analysis of albatross and petrel distribution within the CCAMLR convention area: results from the global Procellariiform tracking database. CCAMLR Science 13, 143-174.

Small, C.J., 2005. Regional Fisheries Management Organisations: their Duties and Performance in Reducing Bycatch of Albatrosses and Other Species. BirdLife International, Cambridge, UK.

Smith, J.L., Morgan, K.H., 2005. An assessment of seabird bycatch in longline and net fisheries in British Columbia. Technical Report Series No. 401. Canadian Wildlife Service, Pacific and Yukon Region, British Columbia.

Suryan, R.M., Craig, D.P., Roby, D.D., Chelgren, N.D., Collis, K., Shuford, W.D., Lyons, D.E., 2004. Redistribution and growth of the Caspian tern population in the pacific coast region of North America, 1981-2000. Condor 106, 777-790.

Suryan, R.M., Dietrich, K.S., Melvin, E.F., Balogh, G.R., Sato, F., Ozaki, K., 2007. Migratory routes of short-tailed albatrosses: use of exclusive economic zones of North Pacific Rim countries and spatial overlap with commercial fisheries in Alaska. Biological Conservation 137, 450-460.

Takekawa, J.E., Harvey, T.E., Carter, H.R., 1990. Decline of the common murre in central California, 1980-1986. Studies in Avian Biology 14, 149-163.

Taylor, B.L., Wade, P.R., De Master, D.P., Barlow, J., 2000. Incorporating uncertainty into management models for marine mammals. Conservation Biology 14, 1243-1252.

Thompson, C.W., Wilson, M.L., Pierce, D.J., DeGhetto, D., 1998. Population characteristics of common murres and rhinoceros auklets entangled in gillnets in Puget Sound, Washington, from 1993 to 1994. Northwestern Naturalist 79, 77-91.

Troutman, B.L., Jeffries, S.J., Young, T.A., 1991. Identification of areas for potential seabird mortality in the commercial salmon gillnet and purse seine fisheries of the Strait of Juan de Fuca and Northern Puget Sound final report. Prepared for the US Fish and Wildlife Service, Refuges and Wildlife Resources, Washington Department of Wildlife, Wildlife Management Division, Nongame Program, Olympia, WA.

Washington Department of Fish and Wildlife, 2000. Puget Sound commercial salmon regulations, Olympia, WA.

Washington Department of Fish and Wildlife, 2007. Species of concern in Washington State. <http://wdfw.wa.gov/wlm/ diversty/soc/soc.htm> (retrieved June 2007).

Weimerskirch, H., Åkesson, S., Pinaud, D., 2006. Postnatal dispersal of wandering albatrosses Diomedea exulans: implications for the conservation of the species. Journal of Avian Biology 37, 23-28.

White, G., Burnham, K.P., 1999. Program MARK: survival estimation from populations of marked individuals. Bird Study 46, S120-S139.

Wilcox, C., Donlan, J.C., 2007. Compensatory mitigation as a solution to fisheries bycatch-biodiversity conservation conflicts. Frontiers in Ecology and the Environment 5, 325-331.

Wilson, U.W., 1991. Responses of three seabird species to El Niño events and other warm episodes on the Washington Coast, 1979-1990. Condor 93, 853-858.

Wilson, U.W., 2003. 2002 Common murre colony surveys with management recommendations for Point Grenville. Unpublished report for the US Fish and Wildlife Service, Washington Maritime Refuges, Port Angeles, WA. 